\title{
Diversity and Distribution of Avifauna at the Montane Cloud Forests of Horton Plains National Park
}

\author{
Chandrasiri P.H.S.P.*, Dharmarathne W.D.S.C. and Mahaulpatha W.A.D. \\ Department of Zoology, University of Sri Jayewardenepura, Sri Lanka \\ *spchandrasiri@gmail.com
}

\begin{abstract}
Diversity and distribution of avifauna was studied at the Tropical Montane Cloud Forests of Horton Plains National Park, situated in the highland plateau of the Nuwara Eliya District from September 2015 to May 2016. Three main habitats were identified; Cloud Forest habitat, Cloud Forest Die-back habitat and Grassland habitat. Three fixed line transacts of $300 \mathrm{~m}$ were marked in each of the habitats using a global positioning system device (GPS). Avifauna was recorded on three consecutive days each month while travelling along transacts, from $0600 \mathrm{~h}$ to $1000 \mathrm{~h}$. Birds were observed through a 10x50 binocular. Opportunistic data and incidental observations were used to supplement the population estimates. Seventy eight species of birds were recorded during the study period. This included 13 endemic species, seven migratory species and 58 resident species. The endemic species were; Sri Lanka White-eye (Zosterops ceylonensis), Sri Lanka Yellow-eared Bulbul (Pycnonotus penicillatus), Sri Lanka Dull-blue Flycatcher (Eumyias sordidus), Sri Lanka Junglefowl (Gallus lafayetii), Sri Lanka Woodpigeon (Columba torringtoniae), Sri Lanka Brown-capped Babbler (Pellorneum fuscocapillus), Sri Lanka Whistling-thrush (Myophonus blighi), Sri Lanka Hill Myna (Gracula ptilogenys), Sri Lanka Ashy-headed Laughingthrush (Garrulax cinereifrons), Sri Lanka Orange-billed Babbler (Turdoides rufescens), Sri Lanka Bush Warbler (Bradypterus palliseri), Sri Lanka Scimitter Babbler (Pomatorhinus melanurus) and Crimson-backed Flameback (Chrysocolaptes stricklandi). A total of 4537 individuals belonging to 60 species were recorded in the cloud forest habitat. And 1870 individuals belonging to 45 species were recorded in the Cloud forest die-back habitat. In the Grassland habitat 2897 individuals belong to 41 species were recorded. The maximum Shannon-Wiener Index (H') of 2.56 was recorded from the Cloud forest habitat. In the Cloud forest die-back habitat the Shannon-Wiener Index H' was 2.49 and in the Grassland habitat it was 2.31. Bird Diversity of Cloud Forest differed significantly from Cloud Forest Die-back bird diversity ( $\mathrm{t}=0.9325, \mathrm{df}=3529)$. Bird Diversity did not differ significantly between Cloud Forest Die-back habitat and the Grassland habitat $(\mathrm{t}=2.2587, \mathrm{df}=3826)$ and between the Cloud Forest and Grassland habitats $(\mathrm{t}=3.9484$, $\mathrm{df}=6484)$. Jaccard Similarity Index between Cloud Forest and Cloud Forest Die-back was 0.58 and these habitats had more similar species. Moreover between Cloud Forest Die-back and Grassland the value was 0.47 and minimum value, 0.4 was recorded between Cloud Forest and Grassland which had less similar species.
\end{abstract}

Keywords: Bird diversity and distribution, Endemic birds, Horton Plains, Tropical Montane Cloud Forest

Proceedings of the International Forestry and Environment Symposium 2016, Department of Forestry and Environmental Science, University of Sri Jayewardenepura, Sri Lanka. 